\title{
北日本における四季成り性イチゴ育種の現状と展望
}

\author{
高橋春實 \\ 秋田県立大学生物資源科学部 010-0444 南秋田郡大潟村南 2
}

\section{Present Status and Prospects of Everbearing Strawberry Breeding in Northern Japan}

\author{
Harumi Takahashi
}

Faculty of Bioresource Sciences, Akita Prefectural University, 2 Minami Ohgata-Mura, Akita 010-0444, Japan

\section{はじめに}

イチゴは $20^{\circ} \mathrm{C}$ 前後の気温を適温としていることから, 本 来, 自然条件下 (露地) では北日本のような冷涼な気候に 適する作物である。しかし，1950 年代に入って農業用のプ ラスチックフィルムが急速に普及してハウス栽培が盛んに なったことから, わが国のイチゴ栽培は暖地中心となった. 本格的なイチゴのハウス栽培は1970年代前半からとされて いる（施山，2001）が，八ウス栽培の普及によってわが国 に打けるイチゴの育種も加温や保温を主体とした促成栽培 や半促成栽培向けの一季成り性品種の育成に主力が注がれ るようになった。しかし，イチゴは夏秋期に扣いても洋菓 子（特にケーキ）用としてかなりの需要があり, 価格的に も高値で取り引きされることから，最近，公的機関，民間 の種苗会社，個人育種家が高温長日期の栽培に向く四季成 り性品種の開発に活発に取り組むようになった。四季成り 性イチゴの品種特性や育種動向については，ここ数年全国

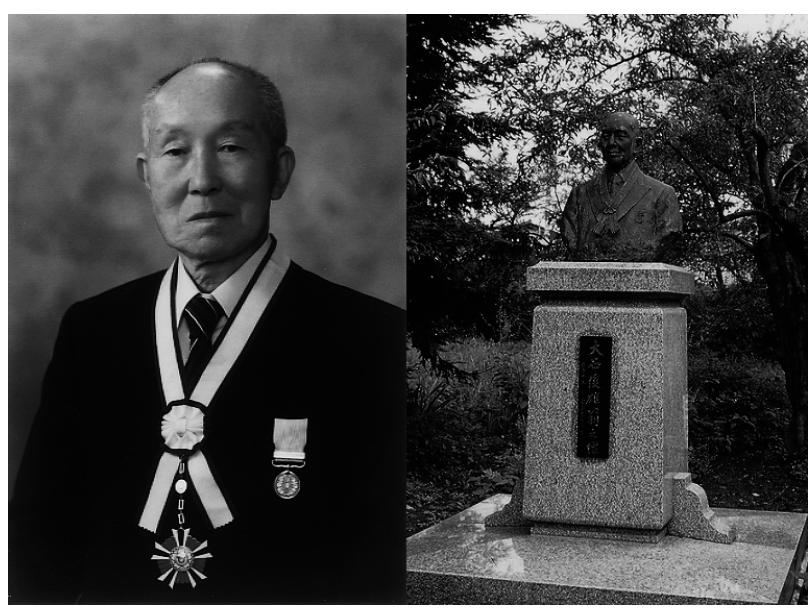

第 1 図 大石俊雄（82 歳）と園芸作物育種等の功績をたたえ て邸内に建立された大石俊雄の胸像（高橋原図）

2006 年 5 月 16 日 受付. 2006 年 6 月 1 日 受理.
的な情報として園芸関係の専門誌や普及誌等で度々取り上 ゲられている（今田，2004; 沖村，2002，2003; 施山，2003; 田村，1999）が，本報では特に東北・北海道地域に打ける 寒冷地の四季成り性品種の育種の現状と展望について述べ てみたい.

\section{わが国における四季成り性イチゴ育種の歴史}

東北・北海道地域に打ける四季成り性イチゴの育種につ いて述べる前に，わが国の四季成り性品種育成の歴史につ いて触れて拈きたい。

イチゴの育種を専門としている研究者や技術者であれば 大石俊雄（1902-1996）（第1図）の名前を一度は耳にした ことがあると思うが，彼がわが国で最初に四季成り性品種 の育成に取り組んだブリーダーであることはイチゴ関係者 の間でも意外に知られていない。 大石は福島県伊達郡保原 町で, 1954 年に苦心の末に“クリムゾン・モナーク’ × ‘鳳 香”の実生から四季成り性の強い個体を選抜して“大石四 季成一号（1954）を育成した（香川，1999; 高橋，2000）. なぜ大石が四季成り性品種の育成に力を注ぐようになった かを知る文献は少ないが，農耕と園芸に掲載された記事， 「イチゴ新品種一大石四季成一号が世に出るまで一イチ ゴ育種三十年の苦心」（大石，1962）の中で，“私は大イチ ゴや芳香イチゴの改良をつづける傍ら，こんなに美味しい イチゴが一年中食べられたらよかららと考えた。誰もがそ ら思うだろう。そのため高冷地で育苗したものを，促成し たり或いは苗の冷蔵までして抑制したり，多大の費用と労 力をかけて季節はずれの生産に努力しているのが現状であ

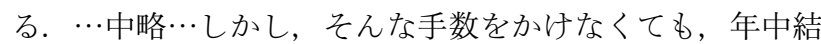
実するイチゴがないわけではない，それは四季成イチゴで ある.” (原文のまま引用)，と述べている，まさに，当時の 日本に拈けるイチゴの育種が一季成り性品種の改良一色で あった時代だけに，彼の発想は独創的であった。しかし， 海外に目を向ければアメリカに打いて最初の実用的な四季 成り性イチゴ品種 ‘Pan American’ の育成が 1902 年である とされているので (Darrow, 1966)，わが国の四季成り性イ 


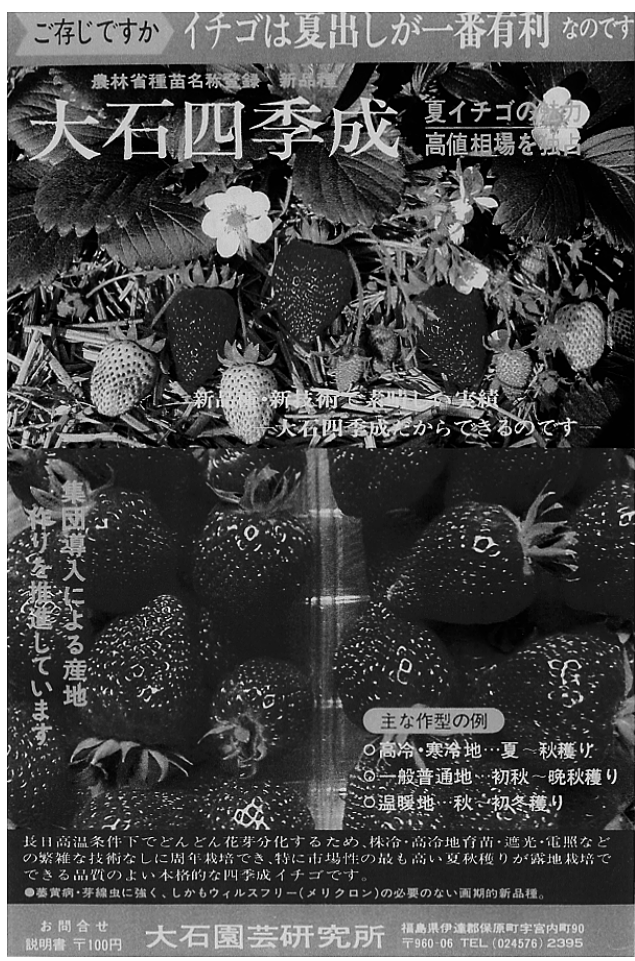

第 2 図大石園芸研究所が ‘大石四季成”普及のために作成し たパンフレット（高橋原図）

パンフレットにはイチゴは夏出しが一番有利であるこ とや ‘大石四季成’ は長日高温条件下で花芽分化するた め, 株冷蔵, 高冷地育苗, 遮光, 電照などの繁雑な技術 なしに周年栽培できることを書いてある
チゴ品種の育成はアメリカよりも約半世紀遅れたことにな る. その後も日本では四季成り性品種の育成にはほとんど 目が向けられず，ようやく1970 年に “大石四季成一号” の 改良種である ‘大石四季成”（第 2 図）が登録されたのみで ある. 著者は, 1999 年の夏に小原町の大石邸を訪ねた折り に，親族の方から四季成り性イチゴの品種育成に情熱を傾 けていた頃の苦労話を聞くことができたが，外国からの情 報や育種素材の導入も極めて限られていた時代に，いち早 く四季成り性品種の必要性を認識し，品種育成まで成し遂 ゲた彼の偉業は，日本に抢けるイチゴ育種史に特筆すべき である。

“大石四季成”の育成後は，公的機関および民間を問わず 1980 年代前半まで四季成り性の新品種育成は見あたらな い. しかし，1980 年代半ばになって寒・高冷地执よび中山 間地の過疎化対策が進められる中で特産品作りの一環とし てょらやく夏秋どり栽培にも徐々に目が向けられるよらに なり（泰松, 1994), “夏芳’ (1986), ‘みよし’ (1987), ‘サマー ベリー’（1988）の3 品種が，また，1991年には ‘エバー ベリー’が相次いで育成された（第 1 表）。これらの品種は 主に四国や中国地方の山間部，北海道などに小面積ながら 定着したことから，四季成り性品種が実用品種として利用 できることを強く印象づけた。その後も，“雷峰”（1992）， “ペチカ’（1995）等, 次々に実用性の高い品種が育成され た (第 1 表)。ここ数年, 四季成り性品種の育成が公的機関 や民間企業等で活発化してきているが，その多くは“とち

第 1 表 わが国で育成された主な四季成り性イチゴ品種 ${ }^{\mathrm{z}}$

\begin{tabular}{|c|c|c|c|c|c|}
\hline 登録年次 & 品種名 ${ }^{y}$ & 育成地 & $\begin{array}{c}\text { 育成者 } \\
\text { (登録者) }\end{array}$ & $\begin{array}{l}\text { 公的機関・ } \\
\text { 民間の別 }\end{array}$ & 交配親 \\
\hline 1954 年 & 大石四季成 1 号 & $\begin{array}{ll}\text { 福 } \text { 島 } \\
\end{array}$ & 大石園芸研究所 & 民 & クリムゾン・モナーク ×鳳香 \\
\hline 1970 年 & 大石四季成 & 福 島 & 大石園芸研究所 & 民 & Institute X2 × 大石四季成一号 \\
\hline 1986 年 & 夏芳 & 奈 良 & 芳岡昭夫 & 民 & (紅の滝 $\times$ 在来種 $) \times$ Aiko \\
\hline 1987 年 & みよし & 徳 島 & 徳島農試 & 公的機関 & 媛育 $\times$ 大石四季成 \\
\hline 1988 年 & サマーベリー & 奈 良 & 奈良農試 & 公的機関 & 夏芳 $\times$ R-1 \\
\hline 1991 年 & エバーベリー & 岩 手 & $\begin{array}{l}\text { 野菜茶試盛岡支場 } \\
\quad \text { (現，東北農業研究センター) }\end{array}$ & 公的機関 & 大石四季成 ×はるよい \\
\hline 1992 年 & 雷峰 & 栃 木 & 市川 清 & 民 & 円雷 $\times$ 女峰自殖系 \\
\hline 1995 年 & ペチカ & 北海道 & ホーブ & 民 & 大石四季成二号 ×サマーベリー \\
\hline 2001 年 & スィートチャーミー & 徳 島 & 川人健一 & 民 & 池光 ×アイベりー \\
\hline 2003 年 & サマープリンセス & 長 野 & 長野南信農試 & 公的機関 & (夏芳 $\times$ 麗紅) $)$ 女峰 \\
\hline 2003 年 & エッチエスー138（夏実） & 北海道 & 北海三共 & 民間 & $\mathrm{HS} 42 \times$ 盛岡 16 号 \\
\hline 2003 年 & カレイニャ（夏んこ） & 北海道 & 畑中克彦 & 民 & サマーベリー×みよし \\
\hline 2005 年 & サマールビー & 徳 島 & ミカモフレテック & 民 & $\begin{aligned} \text { (サマーベリー } & \times \text { みよし }) \times \\
& (\text { アスカウェイブ実生) }\end{aligned}$ \\
\hline 2005 年 & きみのひとみ & 北海道 & 旭川ブリックス & 民 & （女峰 ×サマーベリー）× \\
\hline 出願中 & ほほえみ家族 & 北海道 & 造田芳博, 泰松恒男, 畑中克彦 & 民 & 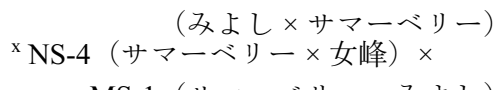 \\
\hline 出願中 & なつあかり & 岩 手 & 東北農業研究センター & 公的機関 & $\begin{array}{l}\text { MS-1（サマーベリー×みよし） } \\
\text { サマーベリー } x \text { 北の輝 }\end{array}$ \\
\hline 出願中 & デコルージュ & 岩手 & 東北農業研究センター & 公的機関 & Pajaro $\times$ 盛岡 26 号 \\
\hline 出願中 & とちひとみ & 栃 木 & 杤木農試 & 公的機関 & 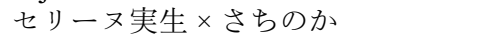 \\
\hline 出願中 & エスポ & 北海道 & ホーブ & 民 & w 大石四季成 2 号 × はるのか \\
\hline 出願中 & サマーキャンディ & 宮 城 & 宮城農業・園芸総合研究所 & 公的機関 & とち打とめ×（M26×サマーベリー） \\
\hline
\end{tabular}

z 沖村（2002）をもとに著者が作表した

$\mathrm{y}$ 太字は東北・北海道地域で育成された品種

$\mathrm{x}, \mathrm{w}$ 著者が育成者（登録者）に直接聞き取り調査を行った 
ひとみ（栃木 18 号）、にみられるよらに収量性だけでなく 果実の大きさ, 日持ち性, 食味等の果実形質や品質を高め ることに重点が扐かれている（稲葉，2004）。

\section{東北・北海道地域における四季成り性品種育成の現状}

先にも述べたよらに, 東北・北海道地域における四季成 り性イチゴの育種は，わが国にとっても最初である‘大石 四季成一号”の育成に始まるが，その後は，“大石四季成” （1970）や“エバーベリー（1991）が発表されただけで, 四季成り性品種の育成は公的機関，民間のいずれにおいて も活発には行われてこなかった。しかし，夏場の輸入イチ ゴの品質 (食味, 果実の着色, 鮮度等) の問題, ポストハー ベストを含めた食の安全・安心に対する消費者の関心の高 まり，7月〜 10 月のイチゴの端境期に打ける洋菓子メー カ一等の強い要望, さらには夏季冷涼な寒地および寒冷地 の気象条件を活かせるといらこともあって, ここ数年東北・ 北海道地域では四季成り性品種の開発が公的機関，民間企 業を問わず精力的に行われている. 2001 年〜2005 年の 5 年間をみても，“エッチエス 138’ (夏実)，“カレイニャ’ (夏んこ)，“きみのひとみ’，“汷汇文家族”，“なつあかり’， ‘デュルージュ’, ‘エスポ’, ‘サマーキャンディ’と相次い で 8 品種が育成されている (第 1 表)。このうち 3 品種は公 的機関で育成されているが，㴗少の5 品種は民間企業で育 成されたものである。このような民間企業の動きは，四季 成り性イチゴの新品種開発をビジネスチャンスの一つと捉 えている現れかもしれない. 上記の品種についての栽培農 家の評価は必ずしも同じではないが, 現在, いずれの品種 も主に夏秋どり栽培に利用する方向で広がりつつあること から，栽培農家だけでなく市場関係者，洋菓子メ一カーお よび消費者からも一定の評価を受けているといってょい.

\section{四季成り性品種育成の課題と展望}

全国的に夏秋どりイチゴが注目されている中で，東北・ 北海道地域は気象的に有利な条件下にあるだけでなく, 2003 年度から東北農業研究センターと東北 6 県の試験研究
機関が共同で「地域農業確立総合研究 寒冷地におけるイ チゴの周年供給システムの確立」に関する大型プロジェク 卜研究（今田，2005）に取り組んでいることもあって，四 季成り性イチゴの栽培技術に関わる試験研究の成果だけで なく新品種開発への期待も大きい. しかし, 著者が 2005 年 に行った東北・北海道地域の公的機関および民間企業への 聞き取り調査からも明らかなように，新品種の開発にあ たってはまだ多くの課題を抱えていることも事実である (第 2 表). 特に公的機関，民間企業を問わず，(1)四季成り 性品種の生理・生態的特性が明らかでない, (2)育種素材と なる品種・系統が少ない，とする回答が多くみられた，最 近，育種素材としての品種や系統は徐々に増えてきている が，育種上重要である四季成り性品種の生理・生態的特性 の解明については，これまで国内では福川ら（2001）, 熊倉 (1994), 西山・金浜 (2002), 西山ら (2003), 施山ら (1989), 施山・今田（1990），泰松（1993），柳（1992）らの研究が あるだけでまだ十分ではなく，今後の研究成果に期待する ところが大きい，その他の課題の中には，公的機関と民間 企業とで異なる回答もあった。 例えば, 公的機関の場合, 四季成り性品種を育成してもその生産物の流通システムが 確立されていない点が問題であるとしているのに対し，民 間企業ではそのことをあまり問題にしていない。むしろ耐 病性や種子系の一代雑種を視野に入れた品種育成を重要視 しているように思われる. すなわち，この違いは公的機関 の場合, 品種育成とその栽培技術の確立（提供）が主体で, 生産物の販売に関しては市場を介した流通に依存している のが一般的であるのに対して，民間企業の場合は新品種の 育成から苗の生産・販売，栽培技術の提供，そして生産物 の販売までを一貫して行ら流通システムを確立している か, 確立できる可能性が高いためではないかと考えられる. 実際，一部の企業では農家との契約栽培によって計画的な 生産と出荷を行い, 独自の流通システムで洋菓子メーカー や消費者にイチゴを届けている例もある.

ほかに，四季成り性品種を育成する上で今後重要と考光 られる点として, 公的機関, 民間企業の双方とも収量性,

第 2 表 四季成り性品種を育成する上での主な課題

\begin{tabular}{cl}
\hline \hline 聞き取り先 $^{z}$ & 課 \\
\hline 公的機関 & ・題 \\
& ・育存の四季成り性品種の生理・生態的特性の解明が十分なされていない \\
& ・季成り性品種と比較して流通システムが不十分である \\
& ・四季成り性品種育成に関しての情報が少ない \\
& ・四季成り性品種を利用する夏どりイチゴの栽培面積が少ない \\
\hline 民間企業 & ・既存の四季成り性品種の生理・生態的特性の解明が十分なされていない \\
& ・耐病性等の育種素材が少ない \\
& ・種子系一代雑種の育種に関する研究と情報が少ない \\
& ・多様なニーズに対応できる育種素材の獲得が難しい \\
\hline
\end{tabular}

（高橋原表，2006）

z 公的機関については北海道抏よび東北 6 県の 7 試験研究機関, 民間については 3 企業に郵送による聞き取り調査を行った. その らち，民間企業の 1 社から回答が得られなかったが，ほかは全て回答があった 
第 3 表 四季成り性品種を育成する上で重要視したい特性

\begin{tabular}{cl}
\hline \hline 聞き取り先 $^{z}$ & \multicolumn{2}{c}{ 重要視する特性 } \\
\hline 公的機関 & 日持ち性, 収量性, 果形の良さ, 大果性, \\
& 高糖度性, 耐病性, 四季成り性の安定 \\
\hline 民間企業 & $\begin{array}{l}\text { 日持ち性, 収量性, 果実の光沢等, 食味, } \\
\text { ランナー発生, 四季成り性の安定 }\end{array}$ \\
\hline
\end{tabular}

（高橋原表，2006）

$\mathrm{z}$ 第 2 表参照

第 4 表 四季成り性品種を育成する上での情報収集

\begin{tabular}{|c|c|}
\hline 聞き取り先 ${ }^{z}$ & 情報収集の方法 \\
\hline 公的機関 & $\begin{array}{l}\text { - 専門雑誌, 新聞等から } \\
\text { - 学会や研究会の発表会に出席して } \\
\text { ・視察や農家から } \\
\text { ・農業改良普及センター等から }\end{array}$ \\
\hline 民間企業 & $\begin{array}{l}\text { - 学会や研究会の発表会に出席して } \\
\text { ・視察や農家から } \\
\text { ・会社独自のルートを利用して } \\
\text { ・専門の研究機関や大学等から }\end{array}$ \\
\hline
\end{tabular}

(高橋原表, 2006)

z 第 2 表参照

日持ち性, 果形 (大果性等), 果実の光沢, ランナー発生の しやすさ, 四季成り性の安定, 食味 (高糖度等), 耐病性等 を挙げている(第 3 表)。これらの目標を達成し, 四季成り 性品種がより満足度の高い品種に改良されるためには時間 を要することではあるが，育成機関相互の情報交換等が必 要不可欠であると考兄られる，著者の調査によれば，四季 成り性品種の育成俰わる情報収集は, 学会・研究会, 専 門雑誌, 新聞, 視察からとしている例が多かった (第 4 表). このことは, 学会や各種研究会の発表会等が専門雑誌や新 聞等と同様に四季成り性品種を育成する上で重要な情報源 になっていることを示している. この様な状況下にあって， 2005 年 10 月に東北大学川内北キャンパスを会場にして開 催された園芸学会公開シンポジゥムの「夏秋どりイチゴ栽 培の現状と将来展望」は時機を得たテーマであった. シン ポジゥムには 300 人以上の参加者があり, その中には園芸 学会会員以外の参加者も多数含まれていた（今田，私信). このことは，とりもな挆さず四季成り性イチゴ品種を含む 夏秋どりイチゴ栽培に研究者や技術者の夕ならず, 生産者, 集出荷団体, 市場関係者, 洋菓子メーカー等が強い関心を 示していることにほかならない.このよらな背景にあって， 今後さらに優良な四季成り性品種の育成とそれに係わる栽 培技術が確立されれば, 東北・北海道地域に打けるイチゴ 生産は夏秋期を中心に拡大が期待できる.

\section{おわりに}

従来, 新品種の開発に関しては, 四季成り性品種, 一季 成り性品種を問わず，育種する側とそれを利用する側（生 産者, 消費者等）との連携が必ずしも密でなかったために,
新品種の特性等が十分理解されないまま利用されずに終 わった品種も数多くある.イチゴに限らず作物の育種には, 長い年月と多くの労力や経費を必要とする．このことを育 種に当たる側と生産物を利用する側が十分認識し, 新しく 生まれた品種が全く利用されないで終わることのないよう にすることが重要である．先に述べたが，現在，東北農業 研究センターが中心となって東北地域を対象に進めている 夏秋どりイチゴに関するプロジェクト研究では, 研究に直 接携わる技術系や社会科学系の研究者の注かに栽培農家, 種苗会社，市場関係者，JA 関係者，菓子メーカー（洋菓子 店を含む)，消費者も加わり総合的に論議しながら，栽培技 術から流通・販売に至るまで種々検討が行われている。そ の成果については，学会等における専門的な発表だけでな く, マニュアル本（東北地域いちご超促成栽培確立プロ ジェクトチーム，2005）や総合研究成果（澤田ら，2005） としても公表されている。 このような大きな動きの中に あって, 東北・北海道地域で育成された四季成り性品種が, 今後，どのように利用されていくのか，著者を含め全国の イチゴ関係者が注目している.

\section{引用文献}

Darrow, G. M. 1966. The Strawberry. P. 165-174. Holt. Rinehart and Winston Publishing, New York.

福川英司・中住晴彦・川岸康司．2001．イチゴ「エッチエ ス-138」の特性. 北海道立農試集報. 81: 41-44.

今田成雄. 2004. 寒冷地に拈けるイチゴの夏秋どり作型の 開発。農耕と園芸. 59: 44-47.

今田成雄. 2005. 短日処理, 越年株利用に上る東北地域に おケる夏秋どりイチゴ栽培一「寒冷地イチゴ」プロジェ クト研究の取り組み一. 園学雑. 74 (別 2) : 70-71.

稲葉幸雄. 2004. 夏秋ぞりに適した四季成りイチゴ新品種 「杤木 18 号」. 農耕と園芸. 59: 56-58.

香川 彰. 1999. 大石四季成. 日本イチゴセミナー紀要, 1999. No. 8: 82-84.

熊倉裕史. 1994. 寒冷地に扔けるイチゴの生理生態的特性 解明と夏秋期生産技術確立に関寸る研究. 神戸大学博 土論文.

Nishiyama, M. and K. Kanahama. 2002. Effects of Temperature and Photoperiod on Flower Bud Initiation of Day-neutral and Everbearing Strawberries. Acta Holt. 567: 253-255.

Nishiyama, M., W. Ohkawa and K. Kanahama. 2003. Effects of Photoperiod on the Development of Inflorescences in Everbearing Strawberry 'Summerberry' Plants Grown at High Temperature. Tohoku J. Agri. Res. 53, No. 3-4: 43-52.

大石俊雄. 1962. イチゴ新品種 大石四季成一号が世に出 るまでイチゴ育種三十年の苦心．農耕と園芸．17: 9597.

沖村 誠. 2002. 四季成りイチゴの品種特性と育種動向. 農耕と園芸. 57: 68-71. 
沖村 誠. 2003. イチゴ品種開発に拈ける内外の動向. 今 月の農業. 47: 18-20.

澤田 守・長根誠二・阿保靜考・田代勇樹・櫻井晃治・ 澁谷 功. 2005. 東北地域に打ける夏秋どりイチゴの 生産・販売の課題. 東北農研総合研究 (A) 第 23 号: 1-98. 施山紀男・三浦周行・今田成雄. 1989. イチゴ品種の生態 特性に関する研究. 第 2 報. 四季成り型と day-neutral 型の成長・開花に対する日長・気温の影響の差異. 園 学雑. 58 (別 1) : 342-343.

施山紀男・今田成雄. 1990. イチゴ品種の生態特性に関す 万研究. 第 5 報. 低温前歴が四季成り性品種の生育々 開花に及洔す影響. 園学雑. 59 (別 2) : 478-479.

施山紀男. 2001. 21 世紀を迎えた日本のイチゴ. 日本イチ ゴセミナー紀要, 2001. No. 10: 8-22.

施山紀男. 2003. イチゴ品種と栽培技術の動向. 今月の農 業. 47: 13-17.

泰松恒雄. 1993. イチゴ四季成性品種生態的特性の解明並
びにその生産性の確立に関する研究．奈良農試特別報 告 : 1-206.

泰松恒雄・西本登志・源田直司・田中良宏. 1994．イチゴ 四季成性品種の生態的特性と栽培技術 [1]，農及園. 69: 395-399.

高橋春實. 2000. 大石四季成一日本に抢任四季成り性イ チゴ育種の先覚者 大石俊雄のプロフィールと育種へ の思い一. 日本イチゴセミナー紀要, 2000. No. 9: 86-91. 田村純二.1999. 日本㸱ける四季成り性品種を利用した夏 秋どり生産. 日本イチゴセミナー紀要，1999. No. 8: 8-14.

東北地域いちごの超促成栽培確立プロジェクトチーム. 2005. 夏秋どりイチゴ栽培マニュアル

柳 智博. 1992. 栽培イチゴ $($ Fragaria $\times$ ananassa Duch $) の$ 四季成り現象に関する研究, とくに温度及び日長の影 響について. 大阪府立大学紀要 農学・生物学. 43: 115-144. 